International Journal of Engineering \& Technology, $7(3.2)(2018) 225-228$
International Journal of Engineering \& Technology
SPC
Website: www.sciencepubco.com/index.php/IJET
Research paper

\title{
The Preliminary Concrete Delay Duration Influence on its Properties at Thermal Processing by Hot Air
}

\author{
TaTiana Kugaevska $^{1}$, Viktor Sopov ${ }^{2}$, Volodymyr Shulgin $^{3}$ \\ ${ }^{I}$ Poltava National Technical Yuri Kondratyuk University, Ukraine \\ ${ }^{2}$ Kharkiv National University Of Civil Engineering And Architecture, Ukraine \\ ${ }^{I}$ Poltava National Technical Yuri Kondratyuk University, Ukraine \\ *Corresponding Author E-Mail: Strelanebo@Ukr.Net
}

\begin{abstract}
Reducing energy consumption in the manufacture of concrete products of factory production is always an urgent task. The use of heated air for creating soft modes of heat treatment of concrete products is proposed. The influence of soft heat treatment modes on the dynamics of the concrete samples strength at an early age has been established. The expediency of using soft heat treatment modes with the obligatory use of hardening accelerators is shown. With this approach, the heat treatment of concrete samples with heated air contributes to increasing the concrete compression strength in the early term of hardening: at the age of 1 day $1.94 \ldots 2.12$ times; at the age of 3 days $1,25 \ldots 1,41$ times.
\end{abstract}

Keywords: heat treatment, concrete, soft mode, compressive strength.

\section{Introduction}

The development of energy saving methods for hydrothermal and thermal treatment of concrete and reinforced concrete products is one of the priority tasks of the concrete studying. One of the ways of developing such methods is the use of solar energy. It is known that the rise in the temperature of hardening (within certain limits) accelerates the chemical reactions of hydration and thus has a beneficial effect on the early concrete strength without any negative consequences for future strength $[1-2]$. However, according to the principle of O.P. Mchedlov-Petrosyan conformity, for providing the necessary properties the time of application and the temperature influences intensity on hardening concrete is in great importance [3].

\section{Overview of the Latest Research Sources and Publications}

Under thermal treatment in the volume of concrete and reinforced concrete products, heterogeneous temperature fields are formed (and in the heat treatment process - also non-uniform fields of moisture content). These factors can lead to the creation of internal mechanical stresses and cause irreversible structural changes in the concrete, and unacceptable reduction of its strength [4-10]. Different temperature regimes are used for energy saving and reducing destructive processes in concrete and reinforced concrete products under thermal treatment $[9,10]$.

The preconditioning of concrete is among a number of measures to avoid these phenomena. The main purpose of this containment is the formation of such an initial structure of concrete, which will provide an opportunity to perceive destructive processes that occur during heat treatment.
Under the heliothermic treatment of concrete and reinforced concrete products under a translucent coating the preconditioning of them is not provided [11, 12]. The expediency of introducing the preconditioning of concrete under heliotherm with the use of an intermediate coolant $[13,14]$ is not considered.

The heat release during cement hydration in precontaining concrete has a positive effect on the formation of solidification products $[3,15-17]$.

\section{Defining Parts of General Problem Which were Not Yet Investigated}

Preconditioning of concrete products in the process of heat treatment is carried out in order to reduce destructive processes in concrete. For the heat treatment of concrete and reinforced concrete products in closed forms heated air can be used [18 - 22]. When combined, the air is heated either in a solar energy collector (Fig. 1), or by an electric air heater.

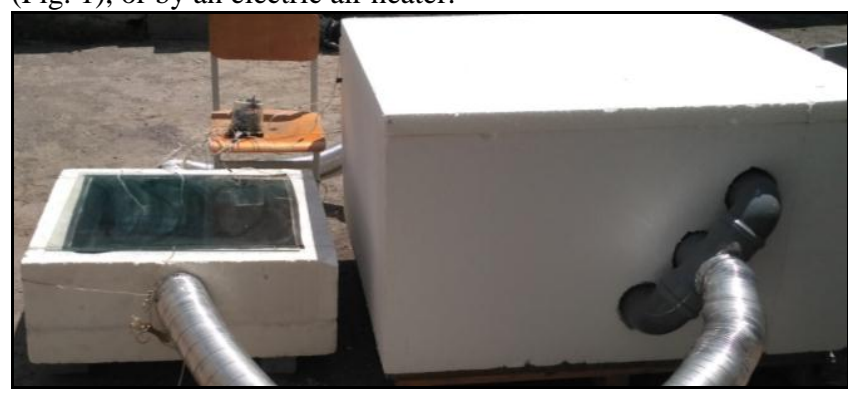

Fig. 1: Use of a solar collector for the heat treatment of waterproofing concrete pavement slabs [18]

This method does not lead to intense heating concrete and, therefore, does not require preconditioning. But such containment can be useful for the development of strength in concrete. 


\section{Aims and Objectives}

The purpose of the research:

- to determine the effect of the pre-containment term during heat treatment of waterproofing samples $(10 \times 10 \times 10 \mathrm{~cm})$ from heavy concrete using heated air (duration of heat treatment of samples with heated air $-3 \mathrm{~h}$; the total term of samples hardening in a laboratory chamber $-21 \mathrm{~h}$ );

- influence of accelerator contents of the concrete strength solidifying at compression at the age of 1 and 3 days (at solidifying concrete using heat treatment and without the use of heat treatment).

\section{Main Body}

Investigation of thermal treatment of waterproof concrete cubes with the use of heated air was carried out in a laboratory installation (Fig. 2). At the sunny day the air was heated in flat solar collectors of domestic construction. In cold season of the year and in cloudy days an infra-red heater was used to heat the air (electric air heater should be used in production units).

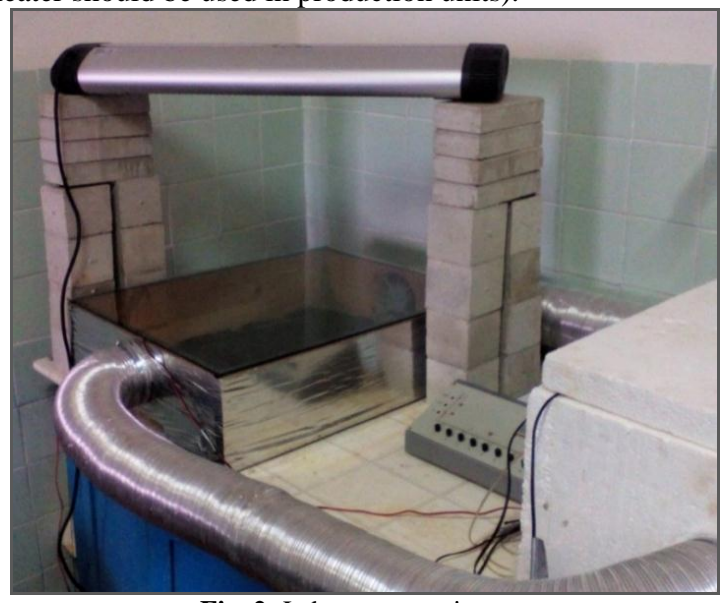

Fig. 2: Laboratory equipment

The study of temperature changes in the chamber was carried out using sensors.

For the study, the composition of the concrete was chosen: 1:1.59:2.66 with the contents of the components: Cement $(\mathrm{PC} \quad \mathrm{I}-500-\mathrm{H})=417.3 \mathrm{~kg} / \mathrm{m}^{3} ;$ Sand $=663.2 \mathrm{~kg} / \mathrm{m}^{3}$; Breakstone $=1112.0 \mathrm{~kg} / \mathrm{m}^{3}$. Water-to-cement ratio was $\mathrm{W} / \mathrm{C}=0.44$. To accelerate the curing processes in the concrete, a chemical admixture based on sodium thiosulfate and sodium rhodanide was used.

The variation in duration of the concrete precontaining in the closed chamber $\tau_{\mathrm{p}}$ and the admixture content in the concrete $\mathrm{d}$, the percentage of the mass of cement in the recalculation on the dry substance was carried out during planning the experiment and the statistical processing of its results (Table 1) [23]. The limits of the admixture content variation are taken within manufacturer's recommendations.

Table 1: The values of the factors variability intervals

\begin{tabular}{|c|c|c|c|}
\hline Code & $\begin{array}{c}\text { Code } \\
\text { values }\end{array}$ & \multicolumn{2}{|c|}{ Values of factors } \\
\cline { 3 - 4 } & & $\begin{array}{c}\mathrm{x}_{1} \\
\text { (duration of precontaining } \\
\text { concrete } \tau_{\mathrm{p}} \text {, hours) }\end{array}$ & $\begin{array}{c}\mathrm{x}_{2} \\
\text { (admixture } \\
\text { content d, \%) }\end{array}$ \\
\hline The main level & 0 & 1 & 1.4 \\
\hline $\begin{array}{c}\text { Variability } \\
\text { interval }\end{array}$ & $\mathrm{x}_{\mathrm{i}}$ & 1 & 0.6 \\
\hline Upper level & + & 2 & 2.0 \\
\hline Lower level & - & 0 & 0.8 \\
\hline
\end{tabular}

Figures 3, 4 show the change in the temperature of solidifying concrete in the chamber (point 1 of the experiment plan). The value of the factors: $\tau_{\mathrm{p}}=2$ hours; admixture content $2.0 \%$.

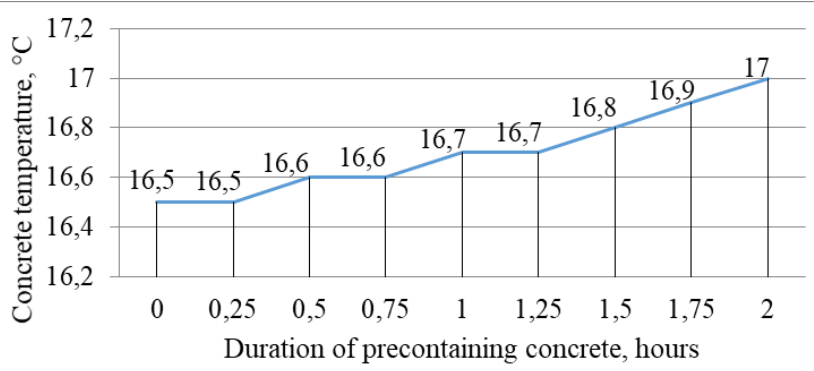

Fig. 3: Change in the temperature of concrete during the precontainment period

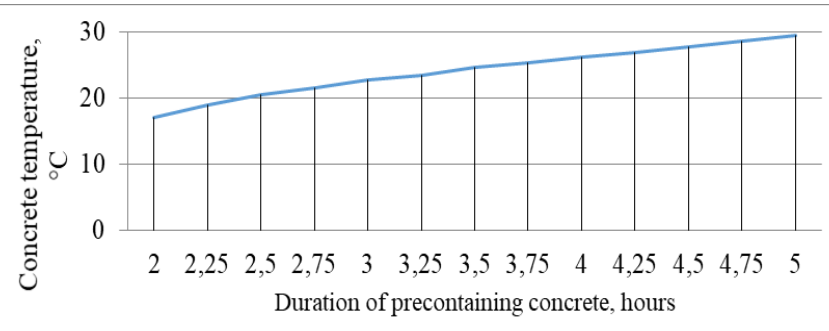

Fig. 4: Change in the temperature of concrete during the heat treatment with hot air

The concrete temperature has increased from 16.5 to $17.0^{\circ} \mathrm{C}$ $\left(\Delta t=0.5^{\circ} \mathrm{C}\right)$ for 2 years of preconditioning. Air temperature in the laboratory at that time was $16.5^{\circ} \mathrm{C}$.

The concrete temperature has increased from 17.0 to $29.4^{\circ} \mathrm{C}$ $\left(\Delta \mathrm{t}=12.4^{\circ} \mathrm{C}\right)$ for 3 years of thermal treatment by heated air. After 21 years of concrete hardening in the chamber its temperature was $23.8^{\circ} \mathrm{C}$.

In subsequent experiments a similar growth intensity of concrete temperature was created during thermal treatment by heated air.

Table 2 shows the concrete compression strength at the age of 1 day and 3 days under heat treatment (HT), and at hardening in air conditions depending on the duration of precontaining concrete $\tau_{\mathrm{p}}, \mathrm{h}$. and the admixture content $\mathrm{d}, \%$.

Table 2: Physical and mechanical properties of concrete

\begin{tabular}{|c|c|c|c|c|c|c|}
\hline \multirow{3}{*}{$\begin{array}{l}\text { Point } \\
\text { of the } \\
\text { plan }\end{array}$} & \multirow[t]{3}{*}{$\begin{array}{c}\tau_{\mathrm{n}} \\
\text { hours }\end{array}$} & \multirow[t]{3}{*}{$\mathrm{d}, \%$} & \multicolumn{4}{|c|}{$\begin{array}{l}\text { Concrete compression strength, } \mathrm{MPa} \text {, } \\
\text { at the age of days }\end{array}$} \\
\hline & & & \multicolumn{2}{|c|}{1} & \multicolumn{2}{|c|}{3} \\
\hline & & & $\begin{array}{c}\text { under } \\
\text { HT }\end{array}$ & $\begin{array}{c}\text { hardening } \\
\text { in air } \\
\text { conditions }\end{array}$ & $\begin{array}{c}\text { under } \\
\text { HT }\end{array}$ & $\begin{array}{l}\text { hardening } \\
\text { in air con- } \\
\text { ditions }\end{array}$ \\
\hline 4 & 0 & \multirow{3}{*}{0.8} & 13.340 & \multirow{3}{*}{6.279} & 20.153 & \multirow{3}{*}{14.245} \\
\hline 8 & 1 & & 12.752 & & 19.206 & \\
\hline 2 & 2 & & 12.166 & & 18.251 & \\
\hline 6 & 0 & \multirow{5}{*}{1.4} & 14.193 & \multirow{5}{*}{6.755} & 21.632 & \multirow{5}{*}{15.421} \\
\hline 9 & 1 & & 13.668 & & 20.574 & \\
\hline 5 & 2 & & 13.125 & & 19.510 & \\
\hline 10 & 1 & & 13.659 & & 20,569 & \\
\hline 11 & 1 & & 13.658 & & 20.567 & \\
\hline 3 & 0 & \multirow{3}{*}{2.0} & 15.074 & \multirow{3}{*}{7.218} & 23.085 & \multirow{3}{*}{16.593} \\
\hline 7 & 1 & & 14.536 & & 21.925 & \\
\hline 1 & 2 & & 13.981 & & 20.734 & \\
\hline
\end{tabular}

On the basis of the recommendations [23], when statistical processing of experimental data, the equations are obtained: - for concrete at the age of 1 day

$\mathrm{y}=13.667-0.5559 \mathrm{x}_{1}+0.8890 \mathrm{x}_{2}-0.0101 \mathrm{x}_{1}^{2}-0.0251 \mathrm{x}_{2}^{2}+$ $+0.0202 \mathrm{x}_{1} \mathrm{x}_{2}$

Fisher's $F_{p}$ criterion $=14.673<19.3$; the regression equation is suitable for use;

- for concrete at the age of 3 days

$\mathrm{y}=20.580-1.0627 \mathrm{x}_{1}+1.3559 \mathrm{x}_{2}-0.0149 \mathrm{x}_{1}{ }^{2}-0.0204 \mathrm{x}_{2}^{2}-$

$-0.1123 \mathrm{x}_{1} \mathrm{x}_{2}$ 
Fisher's $F_{p}$ criterion $=13.867<19.3$; the regression equation is suitable for use.

The construction of the diagram (Figure 5) was carried out according to the following general dependencies:

$x_{1}: y=b_{0}+b_{1} x_{1}+b_{2}+b_{11} x_{1}^{2}+b_{22}+b_{12} x_{1}$;

$x_{2}: y=b_{0}+b_{1}+b_{2} x_{2}+b_{11}+b_{22} x_{2}^{2}+b_{12} x_{2}$.

In this case, when the duration of the previous curing increases, the concrete compression strength at the age of 1 day decreases, and when contents of the hardening accelerator increase (within the limits of the studied) - it increases (Fig. 5).

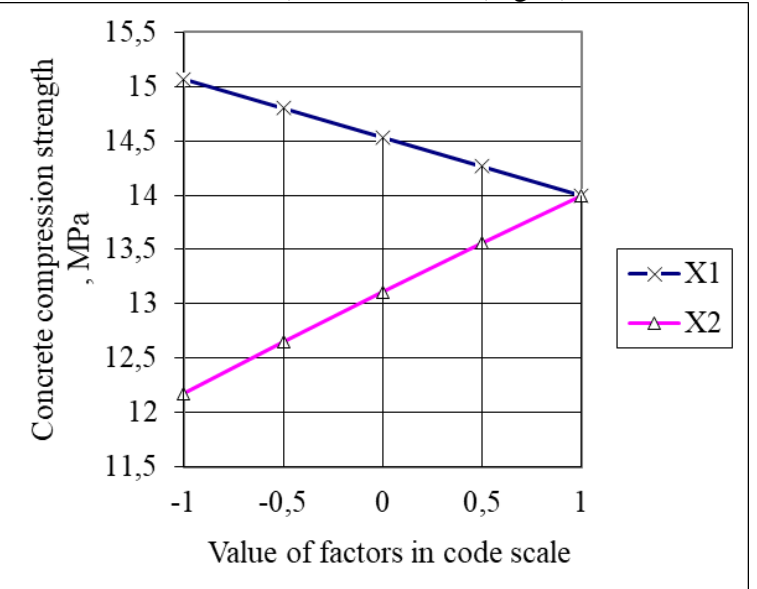

Fig. 5: Concrete compression strength at the age of 1 day depending on the duration of precontainment $\left(\tau_{\mathrm{p}}, \mathrm{h}\right)$ and the admixture content $(\mathrm{d}, \%)$ at maximum level

To construct the diagram (Fig. 6), the following dependencies were used:

$x_{1}: \quad y=b_{0}+b_{1} x_{1}+b_{11} x_{1}^{2} ;$

$x_{2}: \quad y=b_{0}+b_{2} x_{2}+b_{22} x_{2}^{2}$.

In this case, the concrete strength at the age of 1 day within the limits of factors in the code-scale $[-1 \ldots 0]$ dominates influence of the previous containment, and within the limits of factors in the code scale ]0...1] - influence of hardening accelerator (Fig. 6).

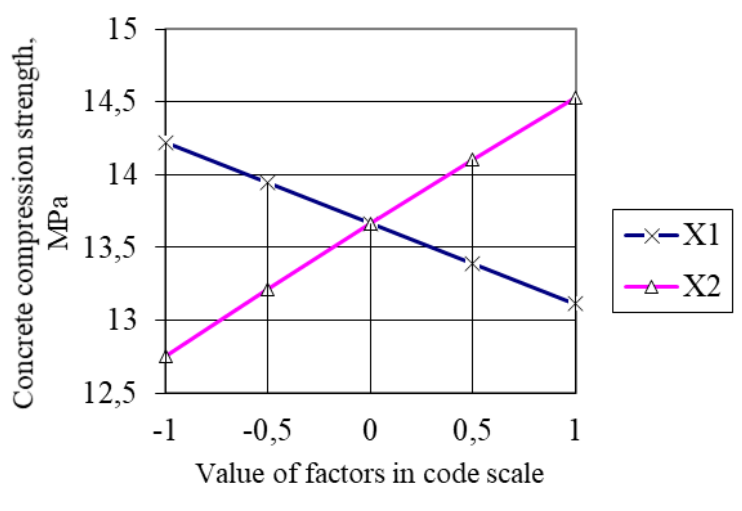

Fig. 6: Concrete compression strength at the age of 1 day depending on the duration of precontainment $\left(\tau_{\mathrm{p}}, \mathrm{h}\right)$ and the admixture content $(\mathrm{d}, \%)$ at main level

The construction of the diagram (Figure 7) was carried out according to the following general dependencies:

$x_{1}: \quad y=b_{0}+b_{1} x_{1}-b_{2} x_{2}+b_{11} x_{1}^{2}+b_{22}-b_{12} x_{1} x_{2} ;$

$x_{2}: \quad y=b_{0}-b_{1} x_{1}+b_{2} x_{2}+b_{11}+b_{22} x_{2}^{2}-b_{12} x_{1} x_{2}$.
In this case, when the duration of the previous curing increases, the concrete compression strength at the age of 1 day reduces, when contents of the hardening accelerator increase (within the limits of the studied) - it increases (Fig. 7).

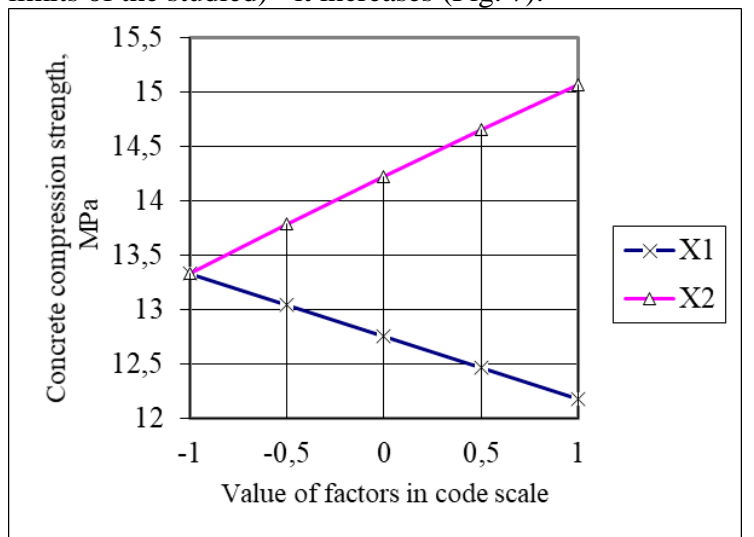

Fig. 7: Concrete compression strength at the age of 1 day depending on the precontainment duration $\left(\tau_{\mathrm{p}}, \mathrm{h}\right)$ and the admixture content $(\mathrm{d}, \%)$ at minimum level

Fig. 8 shows an analysis of the study results at an admixture content of $0.8 \%$

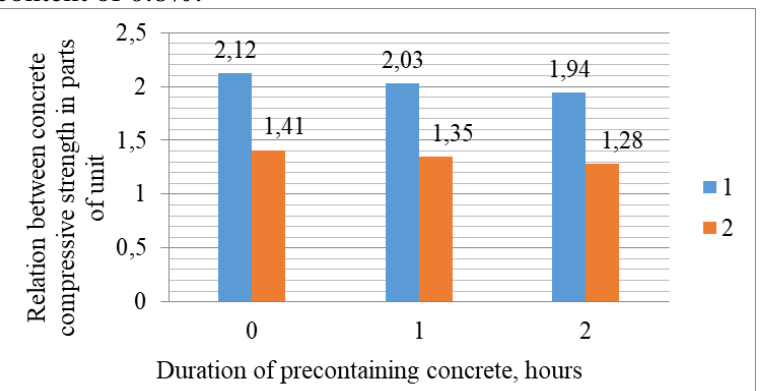

Fig. 8: The relation between the concrete compression strength, solidification of which was carried out with the use of heat treatment and without heat treatment (admixture content $0.8 \%$ ):

1 - at the age of 1 day; 2 - at the age of 3 days

The relation between the concrete compression strength, which was solidified using heat treatment (at $\tau_{\mathrm{p}}=0 \mathrm{~h}$ ), and concrete compression strength, solidification of which occurred without heat treatment (admixture content $0.8 \%$ ):

- at the age of 1 day more than a similar ratio at $\tau_{\mathrm{p}}=1$ hour by $4.2 \%$, at $\tau_{\mathrm{p}}=2$ hours - by $8.5 \%$;

- at the age of 3 days more than a similar ratio at $\tau_{\mathrm{p}}=1$ hour by $4.3 \%$, at $\tau_{\mathrm{p}}=2$ hours - by $9.2 \%$.

Fig. 9 shows an analysis of the study results at an admixture content of $1.4 \%$. The relation between the concrete compression strength, which was solidified using heat treatment (at $\tau_{\mathrm{p}}=0 \mathrm{~h}$ ), and concrete compression strength, solidification of which occurred without heat treatment (admixture content $1.4 \%$ ):

- at the age of 1 day more than a similar ratio at $\tau_{\mathrm{p}}=1$ hour by $3.8 \%$, at $\tau_{\mathrm{p}}=2$ hours - by $7.6 \%$;

- at the age of 3 days more than a similar ratio at $\tau_{\mathrm{p}}=1$ hour by $5.0 \%$, at $\tau_{\mathrm{p}}=2$ hours - by $9.3 \%$.

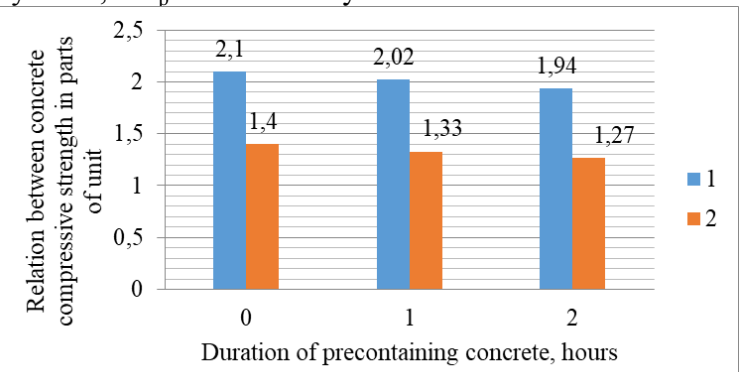

Fig. 9: The relation between the concrete compression strength, solidification of which was carried out with the use of heat treatment and without heat treatment (admixture content $1.4 \%$ ): 
1 - at the age of 1 day; 2 - at the age of 3 days

Fig. 10 shows an analysis of the study results with an admixture content of $2.0 \%$.

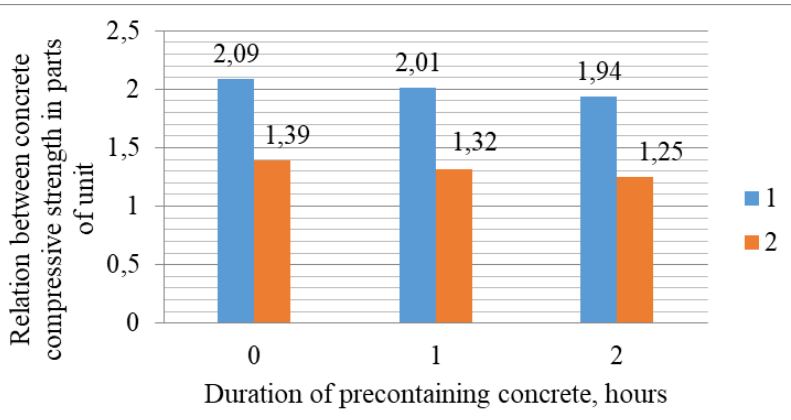

Fig. 10: The relation between the concrete compression strength, solidification of which was carried out with the use of heat treatment and without heat treatment (admixture content $2.0 \%$ ):

1 - at the age of 1 day; 2 - at the age of 3 days

The relation between the concrete compression strength, which was solidified using heat treatment (at $\tau_{\mathrm{p}}=0 \mathrm{~h}$ ), and concrete compression strength, solidification of which occurred without heat treatment (admixture content $2.0 \%$ ):

- at the age of 1 day more than a similar ratio at $\tau_{\mathrm{p}}=1$ hour by $3.8 \%$, at $\tau_{\mathrm{p}}=2$ hours - by $7.2 \%$;

- at the age of 3 days more than a similar ratio at $\tau_{\mathrm{p}}=1$ hour by $5.0 \%$, at $\tau_{\mathrm{p}}=2$ hours - by $10.1 \%$.

The concrete strength (in the studied age) increases with an increase in the hardening accelerator contents from $0.8 \%$ to $2 \%$ both using heat treatment and without heat treatment. Therefore, under these conditions the relation between the concrete compression strength during its hardening with the use of heat treatment and without heat treatment slightly changes.

\section{Conclusions}

It was found that in the soft heat treatment mode of waterproofing slabs of heavy concrete (consisting of hardening accelerator) the presence of pre-containment ( 1 and 2 hours) worsens the intensity of hardening at the age of 1 and 3 days.

The relation between the concrete compression strength, which was solidified using heat treatment (at $\tau_{\mathrm{p}}=0 \mathrm{~h}$ ), and concrete compression strength, solidification of which occurred without heat treatment is greater than the similar ratio:

- at $\tau_{\mathrm{p}}=1$ hour by $3.8 \ldots 4.2 \%$ at the age of 1 day and by $4.3 \% \ldots 5.0 \%$ at the age of 3 days (contents of hardening accelerator: $0.8 \%, 1.4 \%, 2.0 \%)$;

- at $\tau_{\mathrm{p}}=2$ hours at $7.2 \ldots 8.5 \%$ at the age of 1 day and at $9.2 \ldots 10.1 \%$ at the age of 3 days (contents of hardening accelerator: $0.8 \%, 1.4 \%, 2.0 \%$ ).

2. It is shown: the compression strength of heavy concrete, the hardening of which was carried out with the use of investigated heat treatment, exceeds the compression strength of heavy concrete, the hardening of which occurred without heat treatment:

- at the age of 1 day in $1.94 \ldots 2.12$ times (the contents of hardening accelerator: $0.8 \%, 1.4 \%, 2.0 \%$ );

- at the age of 3 days in $1,25 \ldots 1,41$ times (the contents of hardening accelerator: $0.8 \%, 1.4 \%, 2.0 \%$ ).

\section{References}

[1] Saleh A. Al-Saleh, Effect of Extremely Hot and Arid Climate on Concrete Properties, International Journal of Structural and Civil Engineering Research, (2016), Vol. 5, No. 1, pp. $35-38$.

[2] Neville A.M., Properties of Concrete, Pearson Education Limited, Fifth Edition, 2011. - 872 p.

[3] Mchedlov-Petrosyan O.P. Himiya neorganicheskih stroitel'nyh materialov. - M.: Strojizdat, 1988. - 304 s.

[4] Metodika raschyota predel'nyh temperaturnyh gradientov $\mathrm{v}$ zhelezobetonnyh izdeliyah $\mathrm{v}$ processe ehlektroteplovoj obrabotki /
S. V. Fedosov, V. I. Bobylev, A. M. Ibragimov, A. M. Sokolov // Stroitel'nye materialy. - 2011. - № 3. - S. $44-46$.

[5] Modelirovanie vliyaniya gradientov temperatur na raspredelenie napryazhenij na stadii gidratacii betonov / YU. A. Abzaev, A. I. Gnyrya, S. V. Korobkov i dr. // Vestnik TGASU. - Tomsk: TGASU, 2016. - № 3 (56). - S.129 - 138 .

[6] Stepanenko I. V. Tverdenie betonov v usloviyah kontaktnogo podvoda teploty / I. V. Stepanenko // Izvestiya vuzov. Stroitel'stvo. - Novosibirsk: Izd-vo NGASU (Sibstrin), 2012. - № 10 (646). S. $10-13$.

[7] Rahimov A. M. Issledovanie temperaturnyh polej v processe proparivaniya i ostyvaniya betonnyh izdelij v usloviyah povyshennyh temperatur sredy / A. M. Rahimov, B. G. ZHuraev // Simvol nauki. - 2016. - № 2. - S. $72-73$.

[8] Shestakov N. I. Metodika raschyota termo- i vlagonapryazhyonnogo sostoyaniya betonnyh plit, podvergaemyh teplovlazhnostnoj obrabotke N. I. Shestakov, K. V. Aksenchik // Stroitel'nye materialy. - 2012. - № 11. - S. $77-80$

[9] Bibik M. S. Ob ehnergosberegayushchih rezhimah teplovoj obrabotki betonnyh i zhelezobetonnyh izdelij / M. S. Bibik, V. V. Babickij // Stroitel'naya nauka i tekhnika. - 2010. - № 4. S. $55-59$.

[10] Optimizaciya rezhimov teplovlazhnostnoj obrabotki zhelezobetonnyh izdelij i konstrukcij / M. S. Bibik, I. I. Tulupov, V. V. Babickij, S. D. Semenyuk // Resursoekonomni materiali, konstrukciï, budivli ta sporudi: zb. nauk. pr. - Rivne: NUVGP, 2012. - Vip. 23. - S. $22-30$.

[11] Dauzhanov N. T. Low-energy thermal processing technology of foamed concrete products in landfills using solar energy [Electronic resource] / N. T. Dauzhanov, B. A. Krylov. - Access mode: http://vestnikmgsu.ru/index.php/ru/archive/article/download/125.

[12] Use of solar energy for heliothermal treatment of concretes on the basis of alkali cements [Electronic resource] / Zh. T. Aymenov, B. K. Sarsenbayev, N. B. Sarsenbayev, Zh. A. Aldiyarov. - Access mode: https://www.jstage.jst.go.jp/article/jgssp/2/80/2_TC305-08/_pdf.

[13] Aruova L. B. Ispol'zovanie solnechnoj ehnergii dlya geliotermoobrabotki betona v Respublike Kazahstan / L. B. Aruova, N. T. Dauzhanov // Vestnik MGSU. - M.: NIU MGSU, 2012. № $10 .-$ S. $142-145$.

[14] Ushkelbaeva A. O. Geliotermoobrabotka polistirolbetonov, arbolitov cherez geliosistemu s promezhutochnym teplonositelem / A. O. Ushkelbaeva // Vestnik nauki Kazahskogo agrotekhnicheskogo universiteta im. S. Sejfullina. - Astana: KATU, 2015. № 1 (84). - S.192 - 198 .

[15] Fatima A. Al-Qadri. Effect of some admixtures on heat of hydration reaction of cement pastes produced in Yemen, Saudi Arabia, and Egypt / Fatima A. Al-Qadri, A.M. Saad, Affaf Ahmed Aldlaee // Journal of Engineering Sciences, Assiut University. - 2009. Vol. 37, №. 5. - P. 1041-1048.

[16] Greensmith, Christopher Graeme. The effects of cement extenders and water to binder ratio on the heat evolution characteristics of concrete [Electronic resource] / Greensmith, Christopher Graeme. - Access mode: http://wiredspace.wits.ac.za/handle/ 10539/1516.

[17] Uğur Öztürk A. Katkilarin çimento hamuru hidratasyon isisina etkileri [Electronic resource] / A. Uğur Öztürk. - Access mode: http://birimler.dpu.edu.tr/app/views/panel/ckfinder/userfiles/16/files/Der giler/14/08.pdf.

[18] Kugaevska T. S. Vikoristannya sonyachnoï energiï dlya teplovoï obrobki plit betonnih trotuarnih / T. S. Kugaevska, V. P. Sopov, V. V. Shulgin // Budivel'ni materiali ta virobi. - 2017. № 5 - 6 (96). - S. 34 - 36. - Elektronnij resurs: http://reposit.pntu. edu.ua/handle/ PoltNTU/3065.

[19] Kugaevska T. S. Metod doslidzhennya procesiv teplovoï obrobki betonnih virobiv nagritim povitryam / T. S. Kugaevska, V. V. Shulgin, V. P. Sopov // Naukovij visnik budivnictva. - Harkiv: HNUBA, HOTV ABU, 2016. - № 2 (84). - S.245 - 249. - Elektronnij resurs: http://reposit.pntu.edu.ua/handle/PoltNTU/ 1483.

[20] Kugaevska T. S. Kombinovani sposobi geliotermoobrobki betonnih virobiv: monografiya / T. S. Kugaevska. - Poltava: PoltNTU, 2017. - 308 s. - Elektronnij resurs: http://reposit.pntu.edu.ua/handle/ PoltNTU/1494.

[21] Kugaevska T. S. Development of methodology forecasting of intensity solidification concrete products in the alternative methods of heat treatment / T. S. Kugaevska // Energy, energy saving and rational nature use. - Oradea, Romania: Oradea University Press, 2015. - P. 4 - 52. - Elektronnij resurs: http://reposit. pntu.edu ua/handle/PoltNTU/1536.

[22] Kugaevska T. S. Analiz intensivnosti nagrivannya povitrya $v$ ploskomu kolektori sonyachnoï energiï / T. S. Kugaevska, V. V. Shulgin, V. P. Sopov // Naukovij visnik budivnictva. - Harkiv: HNUBA, HOTV ABU, 2016. - 3 (85). - S. 201- 205.

[23] Rukovodstvo po podboru sostavov tyazhyologo betona. - M.: Strojizdat, 1979. $-103 \mathrm{~s}$ 